\title{
Environmental monitoring and recommendations on decreasing the levels of pesticide pollution in Zhytomyr region of Ukraine
}

\author{
Olena Uvayeva $^{1, *}$, Tetiana Vakaliuk $^{2}$, and Dmytro Kostromin ${ }^{1}$ \\ ${ }^{1}$ Zhytomyr Polytechnic State University, Faculty of Mining and Ecology, 103 Chudnivska Str., Zhytomyr, 10005, Ukraine \\ ${ }^{2}$ Zhytomyr Polytechnic State University, Faculty of Information and Computer Technology, 103 Chudnivska Str., Zhytomyr, 10005, \\ Ukraine
}

\begin{abstract}
Environmental monitoring was conducted of facilities for storage and disposal of banned and unsuitable pesticides. Pesticide content in the soil, water, and products of agriculture in the Zhytomyr region of Ukraine was examined, and the accumulation of organochlorine pesticides by freshwater bivalve mollusks was assessed. Storage facilities of the Zhytomyr region contain nearly $392.18 \mathrm{t}$ of pesticides in 137 warehouses, of which 11 meet the requirements, 36 are tolerable, and 90 are in poor condition. In 2018-2019, pesticide content (dichlorodiphenyltrichloroethane (DDT), heptachlor, dichlorodiphenyldichloroethylene (DDE), dichlorodiphenyldichloroethane (DDD), hexachlorocyclohexane (HCH)) was studied in soil and sediments in the Zhytomyr region. The content ranged from 0.0007 to $0.07 \mathrm{mg} / \mathrm{kg}$, which is lower than MPC $(0.1 \mathrm{mg} / \mathrm{kg})$. The content of HCH, DDT, DDE, DDD, and heptachlor was at $0.0007-0.01 \mathrm{mg} / \mathrm{dm}^{3}$ levels in water bodies of the Zhytomyr region in 2018-2019, also lower than MPC. In some samples of soil, water and vegetables, the recorded levels of DDT and organophosphate pesticides Dragon, Dorpan, and Dursban exceeded MPC in 1.5-3.0 times. Traces of organochlorine pesticide Aldrin were found in soft tissues of bivalve mollusks and in the sediments of water bodies they inhabit. Recommendations are proposed to lower the pesticide content in the environment.
\end{abstract}

\section{Introduction}

Ukraine has ratified the Stockholm Convention (23 May 2001) with the Law of Ukraine N 949-V (949-16) of April 18, 2007. According to the Convention, persistent organic pollutants (POP) are recognized as toxic, resistant to decomposition, bioaccumulative, and are subject to transboundary movements by air, water and with migrating species. POP is also deposited at a great distance from the source of their emission, accumulating in terrestrial and aquatic ecosystems [1]. By this convention DDT, aldrin, dieldrin, endrin, chlordane, mirex, toxaphene, heptachlor are included in the list of most dangerous substances.

Long-term application of pesticides has led to largescale environmental pollution over huge territories. The migration of toxic compounds in ecosystems causes the accumulation of residual amounts of pesticides in natural objects.

Organochlorine pesticides (OCP) have been widely used, and some of them still are used in Ukraine [2-7] and other countries [1, 8-14] to control insect pests of agriculture and protect crops. Such as OCP as DDD (dichlorodiphenyldichloroethane),

DDT (dichlorodiphenyltrichloroethane),

DDE (dichlorodiphenyldichloroethylene), and

$\mathrm{HCH}$ (hexachlorocyclohexane) are highly persistent, accumulate for a long time in plants, animals, soils, and are poorly soluble in water. Therefore they usually accumulate in considerable concentration in river sediments and silt.

In Ukraine, OCP has been used most extensively in the 1950-1960s. At the beginning of the 1970s, OCP was shown to be highly toxic to animal organisms. They are also very persistent. DDT does not decompose in the environment for 10 years [6]. When from the environment (soil, water, sediments) OCP enter the living organisms, the compounds circulate in trophic chains of local ecosystems, climbing the trophic levels. Thus, all these components of ecosystems, from producers to consumers of highest levels, contain pesticides in their bodies. DDT and $\mathrm{HCH}$ can accumulate in various organs and tissues (in the case of DDT, mostly in fat tissue). OCP is polytropic compounds, thus they are significantly dangerous to human and animal organisms even in small doses. They negatively affect the functional state of the liver, glands, kidneys and other organs. They have also cytotoxic, carcinogenic, mutagenic effects. All this led to the restriction or ban of their use in the early 1970s. But even today, OCP belongs to the category of widespread pollutants both in Ukraine and abroad.

Content of DDD, DDT, DDE, HCH, DDVP (dichlorvos), 2,4-D (2,4-dichlorophenoxyacetic acid) has been analyzed in rivers of Luhynsky district of Zhytomyr region in 1988-2008. The results of the analysis indicated a significant decrease in pesticide content in the two

$\overline{{ }^{*} \text { Corresponding author: bio-2016@ukr.net }}$ 
decades [4]. That is linked to the discontinuation of large agricultural enterprises that had used public funds to purchase pesticides. At present, only small farms and private homesteads operate in the district.

The long-term, often uncontrolled and unjustified, use of pesticides in agriculture has led to the contamination of inland water bodies with these dangerous toxicants and the disturbance of natural ecological balance. Pesticides of different chemical origin have a detrimental effect on all representatives of freshwater biota. Due to the cumulative properties, pesticides circulate and accumulate in the organisms of all aquatic organisms, including shellfish. In the early XXI century, several scientists [6] have registered persistent OCP (DDT and $\mathrm{HCH}$ ) in various organs of six freshwater mollusk species of the family Unionidae in rivers of Zhytomyr and Khmelnytskyi regions.

In the summer of 2008, several pesticides (DDT, DDE, DDD, $\mathrm{HCH}$, aldrin, dieldrin, and hexachlorobenzene) have been found in bivalve mollusks Colletopterum ponderosum sedakovi (Siemaschko, 1848) in Lake Baikal [8].

I. A. Fodchenko [7] has found pesticides (DDT, aldrin, $\mathrm{HCH}$, heptachlor) in mussels, produced in Ukraine (the Black Sea coast of Odesa region) and abroad (Chile, China). Pesticides have been found in marine mollusks from other countries: Korea [9], Croatia [11], Italy [12], Asian countries [14] and others.

Today, organophosphate pesticides such as chlorophos, paraoxane, metaphos, carbofos, oxamethyl are used more and more frequently [3]. They are less toxic than OCP and do not withstand water, i.e. they are subject to rapid decomposition, which eliminates their prolonged impact on the biota of reservoirs. Today it is important to monitor both the storage conditions of pesticides, a lot of which are still kept in the Zhytomyr Region of Ukraine [15], and the pesticide content in the soil, water bodies, products of agriculture, and in aquatic organisms.

Study aim: to conduct ecological monitoring of pesticides in the Zhytomyr region and to prepare recommendations on decreasing the pesticide levels in the environment.

\section{Material and methods}

Study object is pesticide storage warehouses; samples of water, soil and products of agriculture from Zhytomyr region; freshwater bivalve mollusks of the species Unio crassus (Retzius, 1783) from Perga river (Radovel' village, Olevsky district of Zhytomyr region) (Fig. 1) and Anodonta anatina (Linnaeus, 1758) from Irsha river (Khoroshiv village, Zhytomyr region) (Fig. 2).

The study subject is the ecological monitoring of pesticides in the Zhytomyr region.

The content of pesticides in water, soil, agricultural products and tissues of mollusks was determined based on the State Institution "Zhytomyr Regional Laboratory Center of the Ministry of Health of Ukraine" using standard methods of OCP research, gas-liquid chromatography, and thin-layer chromatography: DSTU EN 1528-1-2002; EN 1528-2:1996; EN 1528-3:1996; EN
1528-4:1996; DSTU EN 12393-(1;2;3):2003; DSTU 4514:2006 [16-18].

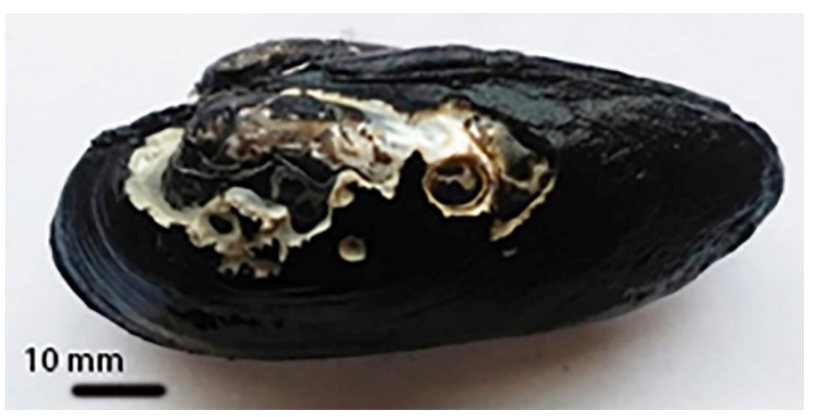

Fig. 1. The shell of Unio crassus (Retzius, 1783) from the Perha river (Radovel' village of Olevsky district, Zhytomyr region).

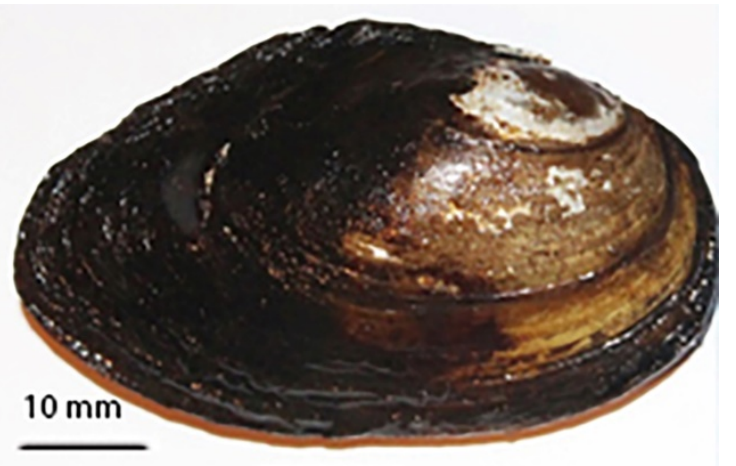

Fig. 2. The shell of Anodonta anatina (Linnaeus, 1758) from the Irsha river (Khoroshiv village, Zhytomyr region).

Information about pesticide storage was given by the Department of Ecology and Natural Resources of Zhytomyr Region State Administration.

Bivalve mollusks were sampled manually at a maximum depth of 0.5-0.7 $\mathrm{m}$ [19]. Most mollusks live on sediments (silt, sandy silt), rarely on sands. Species identification of mollusks was performed based on their conchological features [20].

The results of the study were processed using methods of variation statistics [21].

\section{Results and discussion}

\subsection{The problem of pesticide storage facilities in Zhytomyr region}

Numerous warehouses were built in almost all regions of then-Soviet Ukraine to store various types of pesticides (herbicides, fungicides, insecticides, acaricides, zoocides, etc.). Usually, such pesticides are stored in significantly damaged packages, contaminate the soil and seep into the groundwater. Hence, warehouses that contain pesticides are extremely dangerous. They also have no warning signs and are largely unsecured.

One of the acute environmental problems in the Zhytomyr region is the practice of dealing with unsuitable pesticides and agrochemicals. According to the Department of Ecology and Natural Resources of Zhytomyr Region State Administration, 137 warehouses 
with unsuitable pesticides and agrochemicals are in the Zhytomyr region, as of 01.01.2018 (Fig. 3). Eleven warehouses meet the requirements, 36 are tolerable, and 90 are in poor condition (Fig. 4, 5). The largest warehouses are located in Yahodynka village (Pulynsky district), with 23.00 tons of pesticides; N. Velidnyky village (Ovrutsky district), with 19.49 tons of pesticides at OJSC "Ovrutsky rajagrokhim"; Koshelivka village (Pulynsky district), with 17.0 tons of pesticides; Veselivka village (Ovrutsky district), with 12.07 tons of pesticides at LLC "Nehodivske".

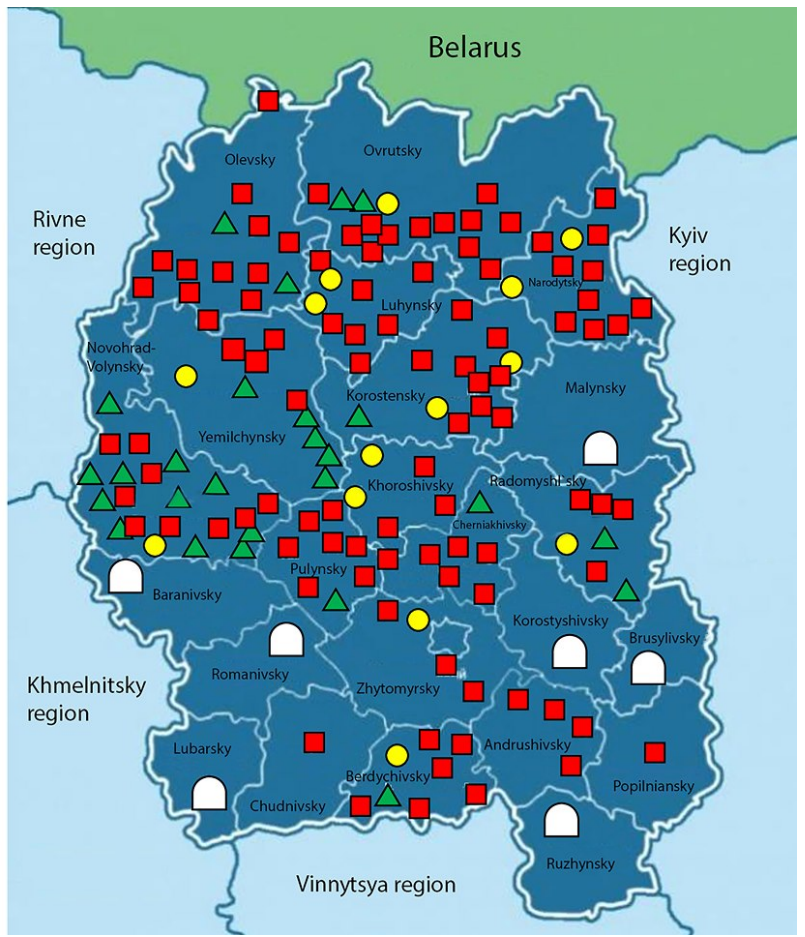

Fig. 3. Map of warehouses storing unsuitable pesticides and agrochemicals in Zhytomyr region, as of 01.01.2018: triangle under $0.5 \mathrm{t}$ of pesticides; circle $-0.5-1.0 \mathrm{t}$ of pesticides; square - more than $1.0 \mathrm{t}$ of pesticides; horseshoe - pesticides were utilized in 2012.

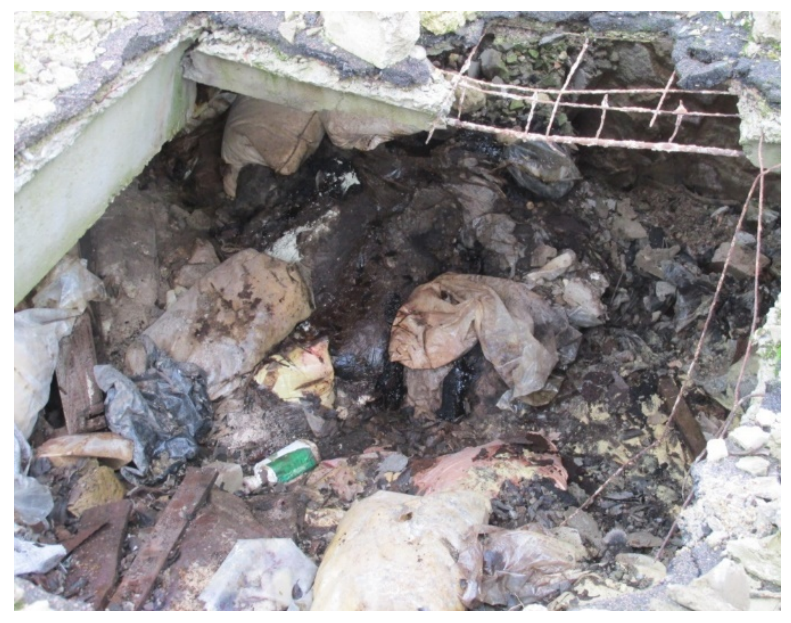

Fig. 4. Pesticide storage in Toporische village of Khoroshiv district, Zhytomyr region (October 2019).

There are a total of $392.18 \mathrm{t}$ of stored pesticides. Of these, $32.450 \mathrm{t}$ are liquid, $24.975 \mathrm{t}$ are solid, and $334.755 \mathrm{t}$ is unknown mixtures. The condition of the storing containers is as follows: $39.07 \mathrm{t}$ of pesticides are kept in good condition, $22.43 \mathrm{t}$ in satisfactory condition, the rest in poor condition. Due to poor storage conditions, toxic pesticides enter the environment including water and air, presenting the risk of poisoning to humans, flora, and fauna.

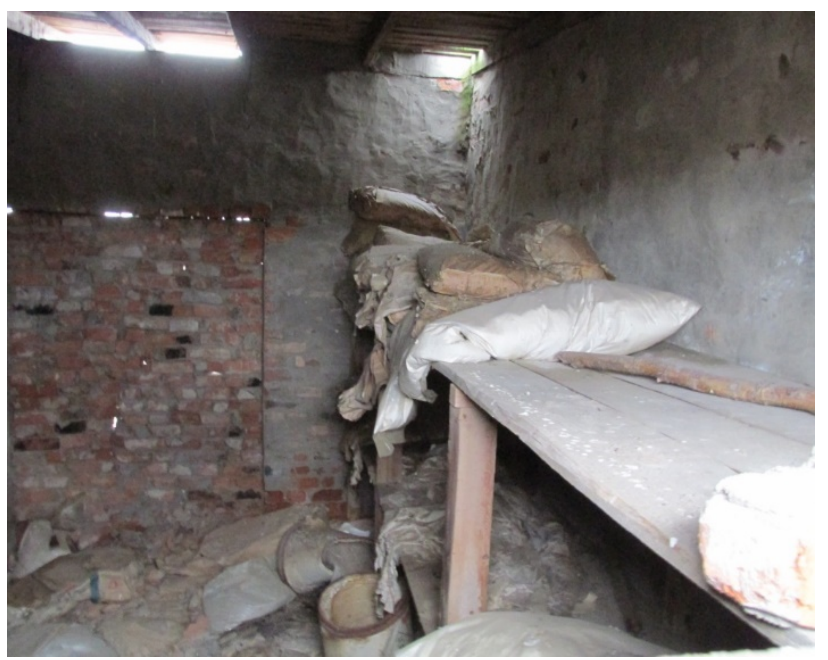

Fig. 5. Pesticide storage in Znamianka village of Khoroshiv district, Zhytomyr region (October 2019).

Only warehouses storing unsuitable chemical plant protection products (CPPP) in Berdychiv and Pulyn districts are protected, the rest of the warehouses are not guarded. In the Zhytomyr region, efforts were made of replacing CPPP containers. For example, $33.731 \mathrm{t}$ of unsuitable agrochemicals of the former collective agricultural enterprises were weighed and reloaded in 11 village councils in Korosten district, in October 2014. $37 \mathrm{t}$ of toxic waste were reloaded in sealed containers at the territories of Novovelidnytska, Nevhodivska, Mozharivska and Pokalivska village councils of Ovrutsky district in 2014. Popilnanska united territorial community (UTC) organized reloading at its own expense of $5.5 \mathrm{t}$ of CPPP to sea containers in 13.05.2017.

In 2011-2012, 968.535 $\mathrm{t}$ of unsuitable CPPP were reloaded and exported from Ukraine. At present, the territory of Baranivsky, Brusyliv, Lubarsky, Malynsky, Romanovsky, and Ruzhyn districts of the Zhytomyr region has been cleared of CPPP.

Expired pesticides are unusable and must be disposed of. Together with storage packaging, they are hazardous waste that must be correctly deactivated by licensed agencies. Currently, in Ukraine, there are no entities licensed to conduct hazardous-waste management (collection, transportation, storage, treatment, disposal), including unsuitable pesticides.

The problem also lies in the lack of a scientifically sound concept of pesticide processing and deactivation, imperfect technological processes and the incomplete technological cycles of processing, the lack of safe methods of disposal. The whole range of issues related to the elimination or control of the negative effects of toxic waste on the environment and human health will only be effectively resolved with a national program for waste 
management.

\subsection{Pesticide pollution of soil, water bodies and products of agriculture in Zhytomyr region}

According to State Institution "Zhytomyr Regional Laboratory Center of the Ministry of Health of Ukraine", pesticide (HCH, DDT, DDE, DDD, heptachlor) content was in the range of $0.0007-0.07 \mathrm{mg} / \mathrm{kg}$ in soils and sediments of Zhytomyr region in 2018-2019, within the MPC values $(0.1 \mathrm{mg} / \mathrm{kg})$ (Table 1$)$.

Table 1. Levels of pollution of soil and sediments with residual amounts of pesticides $(\mathrm{mg} / \mathrm{kg}, \mathrm{MPC}=0.1 \mathrm{mg} / \mathrm{kg})$ in Zhytomyr region (2018-2019).

\begin{tabular}{|c|c|c|c|}
\hline \multirow{2}{*}{ Waterbody } & \multirow{2}{*}{ District } & \multicolumn{2}{|c|}{$\frac{\text { Concentration }}{\text { Pesticide }}$} \\
\hline & & 2018 & 2019 \\
\hline \multirow{4}{*}{ "Stas'ka hreblia" UT MR } & \multirow{4}{*}{$\begin{array}{l}\text { Andruchivka } \\
\text { city }\end{array}$} & $\underline{0.008}$ & $\underline{0.008}$ \\
\hline & & $\mathrm{HCH}$ & $\mathrm{HCH}$ \\
\hline & & $\underline{0.005}$ & $\underline{0.005}$ \\
\hline & & $\overline{\mathrm{DDT}}$ & $\overline{\mathrm{DDT}}$ \\
\hline \multirow{4}{*}{$\begin{array}{l}\text { Unorganized recreational } \\
\text { area in Kvitneve village }\end{array}$} & \multirow{4}{*}{ Andrushivsky } & $\underline{0.01}$ & $\underline{0.009}$ \\
\hline & & $\overline{\mathrm{HCH}}$ & $\overline{\mathrm{HCH}}$ \\
\hline & & $\underline{0.005}$ & $\underline{0.005}$ \\
\hline & & $\mathrm{DDE}$ & DDE \\
\hline \multirow{2}{*}{ Pond of Vchorayshe village } & \multirow{2}{*}{ Ruzhyncky } & $\underline{0.01}$ & $\underline{0.008}$ \\
\hline & & DDD & DDD \\
\hline \multirow{2}{*}{ Lake No.1 } & \multirow{2}{*}{ Korostyshivsky } & $\underline{0.004}$ & $\underline{0.004}$ \\
\hline & & $\mathrm{HCH}$ & $\mathrm{HCH}$ \\
\hline \multirow[t]{2}{*}{ Lake of Glybochok village } & \multirow{2}{*}{ Korostyshivsky } & - & $\underline{0.02}$ \\
\hline & & & $\frac{\mathrm{HCH}}{0.07}$ \\
\hline Quarry (near Zaricchia) & $\begin{array}{l}\text { Korostyshiv } \\
\text { city }\end{array}$ & - & $\underline{\mathrm{HCH}}$ \\
\hline \multirow{2}{*}{ Tykhi Verby pond } & \multirow{2}{*}{ Brusyliv village } & $\underline{0.0008}$ & $\underline{0.0007}$ \\
\hline & & $\mathrm{HCH}$ & $\overline{\mathrm{HCH}}$ \\
\hline \multirow{4}{*}{$\begin{array}{l}\text { Irsha river (unofficial } \\
\text { swimming area), Bondaryk } \\
\text { str. }\end{array}$} & \multirow{4}{*}{ Malyn city } & $\underline{0.008}$ & $\underline{0.007}$ \\
\hline & & $\mathrm{HCH}$ & $\mathrm{HCH}$ \\
\hline & & $\underline{0.005}$ & $\underline{0.005}$ \\
\hline & & $\overline{\mathrm{DDT}}$ & $\overline{\mathrm{DDT}}$ \\
\hline \multirow{3}{*}{$\begin{array}{l}\text { The confluence of Sluch and } \\
\text { Khomora rivers, Baranivka } \\
\text { village }\end{array}$} & \multirow{3}{*}{ Baranivsky } & $\underline{0.07}$ & $\underline{0.07}$ \\
\hline & & $\overline{\mathrm{HCH}}$ & $\mathrm{HCH}$ \\
\hline & & & $\frac{0.06}{\mathrm{DDD}}$ \\
\hline \multirow{2}{*}{ Pond of Chudniv city } & \multirow{2}{*}{ Chudnivsky } & $\underline{0.01}$ & $\underline{0.01}$ \\
\hline & & $\mathrm{H}$ & $\mathrm{H}$ \\
\hline Floodplain of Kodnianka & Ozerne village & & $\underline{0.01}$ \\
\hline river & Ozerne village & - & $\overline{\mathrm{DDD}}$ \\
\hline \multirow{4}{*}{\multicolumn{2}{|c|}{$\begin{array}{l}\text { Notes: MPC - maximum permissible } \\
\text { HCH - hexachlorocyclohexane; } \\
\text { DDT - dichlorodiphenyltrichloroethane; } \\
\text { DDE - dichlorodiphenyldichloroethylene; }\end{array}$}} & \multicolumn{2}{|c|}{ concentration; } \\
\hline & & & \\
\hline & & & \\
\hline & & & \\
\hline DDD - dichlorodiphenyldichl & oroethane; $\mathrm{H}-$ & & \\
\hline
\end{tabular}

In February 2015, an excess of DDT $(0.3 \mathrm{mg} / \mathrm{kg}$, $\mathrm{MPC}=0.1 \mathrm{mg} / \mathrm{kg}$ ) was observed in soil sampled at Romaniv village (Makarenko Street) (report No. 1-10 of February 27, 2015). In September 2017, the content of Dragon pesticide $(0.29 \mathrm{mg} / \mathrm{kg})$ exceeded MPC of $0.2 \mathrm{mg} / \mathrm{kg}$ in soil sampled at the boundary of residential development in the Romanivka village of Brusylivsky district (Centralna str., $1.25 \mathrm{~m}$ from the cornfield) (report No. 148-154 of 28.09.2017). The active substance of Dragon is chlorpyrifos. It belongs to organophosphate compounds. It is a modern, broad-spectrum contact insecticide against sucking and biting insects. It has high initial toxicity, blocking primarily acetylcholine esterase enzymes, which play an important role in the transmission of nerve impulses in insects.

Content of HCH, DDT, DDE, DDD, and heptachlor was measured in water bodies of the Zhytomyr region in 2018-2019 (according to the Zhytomyr Regional Laboratory Center of the Ministry of Health of Ukraine). It fluctuated in the range of $0.0007-0.01 \mathrm{mg} / \mathrm{dm} 3$, which is within MPC values (Table 2).

Table 2. Levels of pollution of water bodies with residual amounts of pesticides $\left(\mathrm{mg} / \mathrm{dm}^{3}\right)$ in Zhytomyr region (20182019)

\begin{tabular}{|c|c|c|c|}
\hline \multirow{2}{*}{ Waterbody } & \multirow[t]{2}{*}{ District } & \multicolumn{2}{|c|}{$\frac{\text { Concentration }}{\text { Pesticide }}$} \\
\hline & & 2018 & 2019 \\
\hline \multirow{4}{*}{ "Stas'ka hreblia" } & \multirow{4}{*}{$\begin{array}{l}\text { Andrushivka } \\
\text { city }\end{array}$} & $\underline{0.009}$ & 0.008 \\
\hline & & $\overline{\mathrm{HCH}}$ & $\overline{\mathrm{HCH}}$ \\
\hline & & $\underline{0.001}$ & $\underline{0.0009}$ \\
\hline & & $\overline{\mathrm{DDT}}$ & $\overline{\mathrm{DDT}}$ \\
\hline \multirow{4}{*}{$\begin{array}{l}\text { Unava river, Kvitneve } \\
\text { village }\end{array}$} & \multirow{4}{*}{ Andruchivsky } & 0.009 & $\underline{0.009}$ \\
\hline & & $\overline{\mathrm{HCH}}$ & $\overline{\mathrm{HCH}}$ \\
\hline & & $\underline{0.001}$ & 0.0009 \\
\hline & & $\overline{\mathrm{DDD}}$ & $\overline{\mathrm{DDD}}$ \\
\hline \multirow{4}{*}{ Pond of Popilnia village } & \multirow{4}{*}{ Popilniansky } & $\underline{0.01}$ & $\underline{0.01}$ \\
\hline & & $\overline{\mathrm{HCH}}$ & $\overline{\mathrm{HCH}}$ \\
\hline & & $\underline{0.001}$ & $\underline{0.001}$ \\
\hline & & DDT & $\overline{\text { DDT }}$ \\
\hline $\begin{array}{l}\text { Waterbody of Khodorkiv } \\
\text { village }\end{array}$ & Popilniansky & - & $\frac{0.0008}{\mathrm{H}}$ \\
\hline \multirow{2}{*}{ Pond in Vchorayshe village } & \multirow{2}{*}{ Ruzhynsky } & $\underline{0.001}$ & $\underline{0.0008}$ \\
\hline & & $\overline{\mathrm{DDD}}$ & $\overline{\mathrm{DDD}}$ \\
\hline \multirow{3}{*}{ Lake "Skirobjednannia" } & \multirow{3}{*}{ Berdychivsky } & \multirow{3}{*}{ - } & $\underline{0.007}$ \\
\hline & & & $\overline{\mathrm{HCH}}$ \\
\hline & & & $\underline{0.001}$ \\
\hline & & 0.006 & \\
\hline Irsha river & Khoroshiv city & $\overline{\mathrm{HCH}}$ & - \\
\hline \multirow{2}{*}{ Vodoyma of Guta village } & \multirow{2}{*}{ Khoroshivsky } & 0.001 & 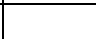 \\
\hline & & $\overline{\mathrm{HCH}}$ & - \\
\hline \multirow{2}{*}{ Lake No. 1} & \multirow{2}{*}{ Korostyshivsky } & $\underline{0.008}$ & - \\
\hline & & $\mathrm{HCH}$ & - \\
\hline \multirow{2}{*}{ Pond of Bezhiv village } & \multirow{2}{*}{ Cherniakhivsky } & $\underline{0.002}$ & - \\
\hline & & $\overline{\mathrm{HCH}}$ & - \\
\hline \multirow{2}{*}{ Tykhi Verby pond } & \multirow{2}{*}{ Brusyliv village } & $\underline{0.0008}$ & 0.0007 \\
\hline & & $\mathrm{HCH}$ & $\mathrm{HCH}$ \\
\hline & & 0.01 & $\underline{0.01}$ \\
\hline $\begin{array}{l}\text { Irsha river (unofficial } \\
\text { swimming area) Bondaryk }\end{array}$ & Malyn city & $\overline{\mathrm{HCH}}$ & $\overline{\mathrm{HCH}}$ \\
\hline & Malyn city & $\underline{0.007}$ & $\underline{0.006}$ \\
\hline & & $\frac{\mathrm{DDT}}{\mathrm{DDT}}$ & $\overline{\mathrm{DDT}}$ \\
\hline "Kaliuzha" (unofficial & & 0.0008 & 0.0005 \\
\hline $\begin{array}{l}\text { swimming area), } \\
\text { Gorodyschanska str. }\end{array}$ & Malyn city & $\mathrm{DDE}$ & DDT \\
\hline Pond of Malynivka village & & & 0.0009 \\
\hline (unofficial swimming area) & Malynsky & - & DDE \\
\hline Viznia river, in Rudnia- & Malynsky & $\underline{0.0008}$ & - \\
\hline Gorody-schenska village & Malynsky & DDE & - \\
\hline & & $\underline{0.008}$ & \\
\hline Myka river (unofficial & Dodomuchl'str & $\overline{\mathrm{HCH}}$ & 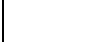 \\
\hline swimming area) & Radomyshi sky & $\underline{0.0009}$ & \\
\hline & & $\mathrm{H}$ & \\
\hline Teteriv river $(250 \mathrm{~m}$ & & & \\
\hline $\begin{array}{l}\text { downstream of waste-water } \\
\text { discharges) }\end{array}$ & Radomyshl'sky & DDD & - \\
\hline
\end{tabular}




\begin{tabular}{|c|c|c|c|}
\hline \multirow{2}{*}{ Waterbody } & \multirow{2}{*}{ District } & \multicolumn{2}{|c|}{$\frac{\text { Concentration }}{\text { Pesticide }}$} \\
\hline & & 2018 & 2019 \\
\hline $\begin{array}{l}\text { Sluch river ( } 200 \mathrm{~m} \text { upstream } \\
\text { of waste-water discharges of } \\
\text { communal enterprise } \\
\text { "Novohrad-Volynsky } \\
\text { VUVKH") }\end{array}$ & $\begin{array}{l}\text { Novohrad- } \\
\text { Volynsky }\end{array}$ & $\frac{0.009}{\mathrm{HCH}}$ & - \\
\hline $\begin{array}{l}\text { Sluch river ( } 200 \mathrm{~m} \\
\text { downstream of waste-water } \\
\text { discharges of communal } \\
\text { enterprise "Novohrad- } \\
\text { Volynsky VUVKH") } \\
\end{array}$ & $\begin{array}{l}\text { Novohrad- } \\
\text { Volynsky }\end{array}$ & $\underline{0.01}$ & - \\
\hline $\begin{array}{l}\text { Sluch river (recreational area } \\
\text { near Zaricchia) }\end{array}$ & Baranivka city & $\frac{0.005}{\mathrm{HCH}}$ & $\begin{array}{l}\frac{0.001}{\mathrm{HCH}} \\
\frac{0.001}{\mathrm{H}}\end{array}$ \\
\hline $\begin{array}{l}\text { The confluence of Sluch and } \\
\text { Khomora rivers, Markivka } \\
\text { village }\end{array}$ & Barankivsky & $\frac{0.007}{\mathrm{HCH}}$ & $\frac{0.0008}{\mathrm{H}}$ \\
\hline Pond of a brick factory & Pulyny village & $\underline{\mathrm{O}} \mathrm{\textrm {HCH }}$ & $\frac{0.009}{\mathrm{HCH}}$ \\
\hline $\begin{array}{l}\text { Teteriv river ( } 100 \mathrm{~m} \\
\text { upstream of the bridge) }\end{array}$ & Chudniv city & $\underline{0.006}$ & $\frac{0.0009}{\text { DDT }}$ \\
\hline Pond of Chudniv city & Chudniv city & - & $\frac{0.0007}{\mathrm{H}}$ \\
\hline
\end{tabular}

Notes: $\mathrm{HCH}$ - hexachlorocyclohexane $\left(\mathrm{MPC}=0.02 \mathrm{mg} / \mathrm{dm}^{3}\right)$; DDT - dichlorodiphenyltrichloroethane $\left(\mathrm{MPC}=0.002 \mathrm{mg} / \mathrm{dm}^{3}\right)$; DDE - dichlorodiphenyldichloroethylene

(MPC $\left.=0.002 \mathrm{mg} / \mathrm{dm}^{3}\right) ; \mathrm{DDD}$ - dichlorodiphenyldichloroethane $\left(\mathrm{MPC}=0.002 \mathrm{mg} / \mathrm{dm}^{3}\right) ; \mathrm{H}-$ Heptachlor $\left(\mathrm{MPC}=0.001 \mathrm{mg} / \mathrm{dm}^{3}\right)$; dash - no data available.

In September 2017, the content of Dragon (0.003$\left.0.004 \mathrm{mg} / \mathrm{dm}^{3}\right)$ and Dorpan $\left(0.003 \mathrm{mg} / \mathrm{dm}^{3}\right)$ pesticides exceeded MPC values $\left(0.002 \mathrm{mg} / \mathrm{dm}^{3}\right)$ in waters of private dug out wells on the Centralna and Shevchenko streets of Romanivka village, Brusylivsky district (report No. 297-301 of 28.09.2017). The active substance of Dorpan is chlorpyrifos, one of the organophosphate compounds. It is a broad-spectrum insecticide.

In August 2016, the content of Dursban pesticide $(0.1 \mathrm{mg} / \mathrm{kg})$ exceeded MPC of $0.05 \mathrm{mg} / \mathrm{kg}$ in vegetables (zucchini) produced in Yastrubna village of Brusylivsky district (report No. 44 of 4.08.2016). The active substance of Dursban is also chlorpyrifos.

\subsection{Accumulation of organochlorine pesticides by freshwater bivalve mollusks}

We studied the organochlorine pesticide content in soft tissues of bivalve mollusks of the species Unio crassus from the Perha river (Radovel' village, Olevsky district) and Anodonta anatina from Irsha river (Khoroshiv village, Zhytomyr region), and also in water and sediments of rivers inhabited by the mollusks. OCP enters the mollusk organisms the same as other pesticides, either through the skin, adsorption with food, or with metabolism. OCP is accumulated most intensively in the body parts of mollusks that are most exposed to the polluted environment (shell, mantle, foot, and branchia).

$\mathrm{HCH}, \mathrm{DDT}, \mathrm{DDD}$, DDE, heptachlor were not detected in water, sediments, and tissues of bivalve mollusks by gas-liquid chromatography. Thin-layer chromatography revealed traces of Aldrin pesticide in sediments and soft mollusks (Fig. 6).
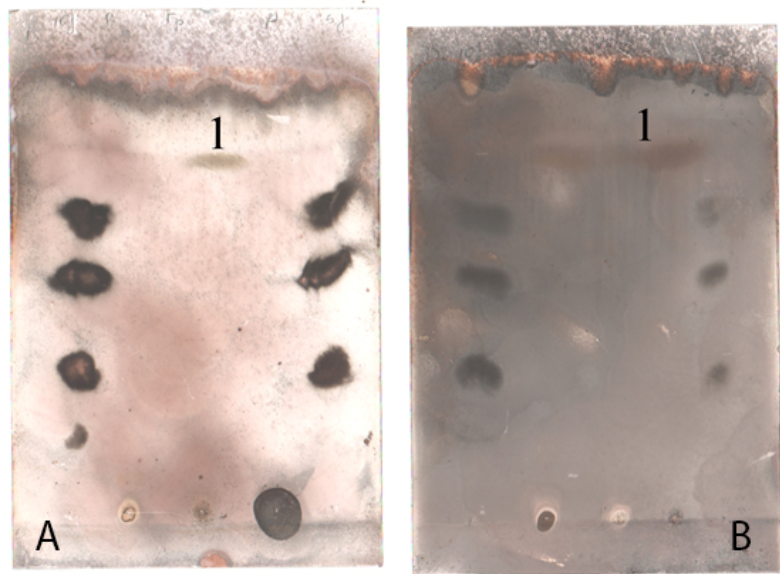

Fig. 6. Chromatogram of distribution of organochlorine pesticides on chromatogramic plate "Silufol", thin-layer chromatography (solvent system hexane, developer silver ammonia, September 2019): A - foot tissues of Unio crassus mollusks from the Perha river (Radovel' village, Olevsky district of Zhytomyr region); B - foot tissues of Anodonta anatina mollusks from Irsha river (Khoroshiv village, Zhytomyr region), 1 - trace amounts of Aldrin.

Aldrin is a pesticide, used in pest control in plant cultures and against termites. Due to its toxic effect, it is banned not only for use but also for production in Ukraine and many other countries of the world. At the same time, Aldrin reserves may be kept in numerous pesticide storages in Ukraine.

\subsection{Recommendations for decreasing pesticide content in the environment}

The development of scientific technologies and legislative framework is important in controlling and lessening the negative effects of pesticides on the environment. Hence, the following recommendations are topical:

- the implementation of the Stockholm Convention on Persistent Organic Pollutants in Ukraine should become a matter of national priority;

- there should be scientific studies and development concerned with the determination and monitoring of pesticides;

- system of state monitoring of environment and citizen health under the effect of pesticides should be implemented;

- the infiltration of pesticides into the environment should be limited and/or prevented;

- control should be established over economic entities that produce and sell (or otherwise realize) pesticides, and over citizens or other legal entities engaged in activities related to such pesticides;

- people of Ukraine should be informed of the dangers of pesticides;

- training programs should be developed and implemented on pesticide hazards and their implications for the life and health of humans, the environment, and of alternatives to pesticides; 
- illegal circulation of pesticides in Ukraine, circulation of banned and overdue pesticides should be prevented, and areas contaminated with pesticides that are unsuitable or banned to use should be detected and cleared.

\section{Conclusions}

In the Zhytomyr region, nearly $392.18 \mathrm{t}$ of pesticides are stored in 137 warehouses. The quality of storage containers is as follows: $39.07 \mathrm{t}$ is kept in good condition; $22.43 \mathrm{t}$ is kept intolerable conditions; other pesticides are stored in containers of poor quality. In 2018-2019, pesticide (HCH, DDT, DDE, DDD, heptachlor) content in soils and sediments of the Zhytomyr region was in the range of $0.0007-0.07 \mathrm{mg} / \mathrm{kg}$, i.e. within MPC values $(0.1 \mathrm{mg} / \mathrm{kg})$. Content of $\mathrm{HCH}$, DDT, DDE, DDD, heptachlor in water bodies of Zhytomyr was in the range of $0.0007-0.01 \mathrm{mg} / \mathrm{dm}^{3}$, at the same time, also within MPC. In 2015, DDT content in soil $(0.3 \mathrm{mg} / \mathrm{kg})$ exceeded MPC $(0.1 \mathrm{mg} / \mathrm{kg})$ in Romaniv village; in 2017, Dragon pesticide content in soil $(0.29 \mathrm{mg} / \mathrm{kg})$ exceeded MPC $(0.2 \mathrm{mg} / \mathrm{kg})$ in Romanivka village. Also in 2017, Dragon pesticide content $\left(0.003-0.004 \mathrm{mg} / \mathrm{dm}^{3}\right)$ and Dorpan pesticide content $\left(0.003 \mathrm{mg} / \mathrm{dm}^{3}\right)$ exceeded MPC $\left(0.002 \mathrm{mg} / \mathrm{dm}^{3}\right.$ and $0.002 \mathrm{mg} / \mathrm{dm}^{3}$, respectively) in water samples from wells of Romanivka village. In August 2016, Dursban pesticide content $(0.1 \mathrm{mg} / \mathrm{kg})$ exceeded MPC $(0.05 \mathrm{mg} / \mathrm{kg})$ in sampled zucchini produced in Yastrubna village of Brusylivsky district, Zhytomyr region. In soft tissues of bivalve mollusks and sediments of the water bodies which they inhabit, residual traces of the organochlorine pesticide Aldrin were found.

\section{References}

1. Stokgholjmsjka konvencija pro stijki orghanichni zabrudnjuvachi: Konvenciju ratyfikovano Zakonom No. 949-V (949-16) vid 18.04.2007, VVR) (Ratification of Stockholm Convention on persistent organic pollutants by Law of Ukraine No. 949-V (949-16) of 18.04.2007, BBP), 2007, No. 30, art.396, http://www.zakon4.rada.gov.ua/laws/show/995_a07. Accessed 28 Sep 2019

2. A. F. Bezvynny, O. O. Mysliuk, Zneshkodzhennja neprydatnykh pestycydiv - naghaljna problema sjoghodennja (Deactivation of unsuitable pesticides an urgent problem of today). Visnyk ChDTU 1, 140143 (2008)

3. S. V. Dudnyk, M. Yu. Yevtushenko, Vodna toksykologhija: osnovni teoretychni polozhennja ta jikhnje praktychne zastosuvannja (Aquatic toxicology: basic theoretical concepts and their practical application). (Vyd-vo of Ukr. Phytosociol. Center, Kyiv, 2013)

4. T. M. Kotkova, S. L. Rybal'chenko, G. O. Selezniova, Analiz zabrudnennja vod richky Zherev ta jiji osnovnykh prytok pestycydamy ta jikh vplyv na vodnu mikrofloru (Analysis of water pollution in Zherev river and its main tributaries by pesticides, and their impact on aquatic microflora), in Scientific readings - 2013, scientific-theoretical proceedings, vol. 1 (ZhNAEU, Zhytomyr, 2013), pp. 94-97

5. E. A. Pichugin, Metody, sposoby i tekhnologii obezvrezhivaniya i utilizatsii opasnykh stoykikh organicheskikh zagryazniteley (Methods and technologies for the deactivation and disposal of hazardous persistent organic pollutants). Ecology of urbanized territories 3, 40-46 (2016)

6. A. P. Stadnychenko, L. M. Yanovich, Nakopychennja khlororghanichnykh pestycydiv prisnovodnymy dvostulkovymy moljuskamy (Mollusca: Bivalvia: Unionidae) (Accumulation of organochlorine pesticides by freshwater bivalve mollusks (Mollusca: Bivalvia: Unionidae)). Visnyk DAU 1, 113-117 (2004)

7. I. A. Fodchenko, Porivnjaljnyj analiz vmistu KhOP u dvostulkovykh moljuskakh $\mathrm{v}$ Ukrajini ta inshykh derzhavakh svitu (Comparative analysis of OCP content in bivalve mollusks in Ukraine and other countries of the world). Bulletin of Sumy National Agrarian University, 11(47), 65-70 (2017)

8. G. S. Shyrapova, G. S. Utiuzhnikova, G. G. Matafonova, D. V. Matafonov, Colletopterum ponderosum sedakovi - perspektivnyy bioindikator zagryaznennosti khlororganicheskimi pestitsidami ozera Baykal (Colletopterum ponderosum sedakovia promising bioindicator of pollution levels of organochlorine pesticides in Lake Baikal), in Youth and Science in Zabaikalie, Proceedings of the conference of young scientists (Izd-vo ZabGGPU, Chita, 2008), p. 104

9. H.G. Choi, H.B. Moon, M. Choi, J. Yu et al., Mussel watch program for organic contaminants along the Korean coast, 2001-2007. Environmental monitoring and assessment 169(1-4), 473-485 (2010)

10. H. Hellar-Kihampa, K. De Wael, E. Lugwisha, G. Malarvannan, A. Covaci, R. Van Grieken, Spatial monitoring of organohalogen compounds in surface water and sediments of a rural-urban river basin in Tanzania. Science of The Total Environment 447, 186-197 (2013). doi:10.1016/j.scitotenv.2012.12.083

11. Z. Kljaković-Gašpić, S. Herceg-Romanić, D. Kožul, J. Veža, Biomonitoring of organochlorine compounds and trace metals along the Eastern Adriatic coast (Croatia) using Mytilus galloprovincialis. Marine pollution bulletin 60(10), 1879-1889 (2010)

12. R.A. Monteduro, F. Pellizzato, L. Sperni, B. Pavoni, Contamination in Mytilus galloprovincialis by chlorinated hydrocarbons (PCBs and pesticides), PAHs and heavy metals in the lagoon of Venice. Polycyclic Aromatic Compounds 27(5), 437-459 (2007)

13. K. Nomiyama, Y. Uchiyama, S. Horiuchi, A. Eguchi, H. Mizukawa, S. H. Hirata, R. Shinohara, S. Tanabe, Organohalogen compounds and their metabolites in the blood of Japanese amberjack (Seriola quinqueradiata) and scalloped hammerhead shark 
(Sphyrna lewini) from Japanese coastal waters. Chemosphere 85(3), 315-321 (2011). doi:10.1016/j.chemosphere.2011.06.092

14. K. Ramu, N. Kajiwara, A. Sudaryanto et al., Asian Mussels Watch Program: Contamination Status of Polybrominated Diphenyl Ethers and Organochlorines in Coastal Waters of Asians Countries. Environmental science \& technology 41(13), 4580-4586 (2007)

15. D.O. Kostromin, O.I. Uvayeva, Problema skladiv pestycydiv na terytoriji Zhytomyrsjkoji oblasti (The problem of pesticide storage in Zhytomyr region), in Proceedings of All-Ukrainian Scientific and Practical Conference of Higher Education and Young Scientists "Sustainable development of Ukraine in the framework of integration to EU", November 7, 2019, Zhytomyr, Zhytomirska Politekhnika, pp. 116-117

16. DSanPiN 8.8.1.2.3,4-000-2001 Dopustymi dozy, koncentraciji, kiljkosti ta rivni vmistu pestycydiv u siljsjkoghospodarsjkij syrovyni, kharchovykh produktakh, povitri robochoji zony, atmosfernomu povitri, vodi vodojmyshh, grunti, zatverdzheni Ministerstvom okhorony zdorov'ja Ukrajiny (DSanPiN 8.8.1.2.3,4-000-2001 Permissible doses, concentrations, quantities and levels of pesticides in agricultural raw materials, foodstuffs, working area air, atmospheric air, water bodies of water, soils approved by the Ministry of Health of Ukraine) 09/20/01, No. 137 (2001)

17. DSTU 4514:2006. Ryba, inshi vodni zhyvi resursy ta kharchova produkcija $\mathrm{z}$ nykh. Vyznachannja khlororghanichnykh pestycydiv ta polikhlorovanykh bifeniliv metodom ghazoridynnoji khromatoghrafiji. Zaghaljni polozhennja (DSTU 4514:2006. Fish and other aquatic living resources, and derived food products. Determination of organochlorine pesticides and polychlorinated biphenyls with gas-liquid chromatography. Terms) (Derzhstandart of Ukraine, Kyiv, 2006)

18. M.A. Klisenko et al., Metody opredeleniya mikrokolichestv pestitsidov $v$ produktakh pitaniya, kormakh $i$ vneshney srede (Methods for the determination of trace amounts of pesticides in food and the environment). (Kolos, Moscow, 1992)

19. O.A. Skarlato, Ya.I. Starobohatov, N.I. Antonov et al., Metody yzuchenyja dvustvorchatykh molljuskov (Methods of studying bivalve mollusks). (Leningrad, 1990)

20. A. Piechocki, B. Wawrzyniak-Wydrowska, Guide to the freshwater and marine mollusca of Poland (Bogucki Wydawnictwo Naukowe, Poznań, 2016)

21. L. O. Antrametova. Biometrija, Chastyna I (Biometrics, vol. I). (Ranok, Kharkiv, 2007) 